\title{
Solvent Effects in Asymmetric Hetero Diels-Alder and Ene Reactions
}

\author{
Mogens Johannsen and Karl Anker Jørgensen* \\ Department of Chemistry \\ Aarhus University \\ DK-8000 Aarhus C, Denmark
}

\begin{abstract}
The use of polar solvents such as nitromethane or 2-nitropropane leads to a significant improvement of the catalytic properties of a cationic copper-Lewis acid in the hetero Diels-Alder reaction of alkyl glyoxylates with dienes. The scope of a newly developed copper(II)-bisoxazoline catalyst for the hetero Diels-Alder reaction is demonstrated by the reaction of different dienes with alkyl glyoxylates in nitroalkane solvents with the formation of the hetero Diels-Alder adduct in high enantiomeric excess as the major product. The synthetic application of the reaction is exemplified by an improved synthesis of a highly interesting synthon for sesquiterpene lactones.

Copyright $\mathbb{C} 1996$ Elsevier Science Ltd
\end{abstract}

\section{Introduction}

The Diels-Alder (DA) reaction is one of the cornerstones in organic chemistry, as it allows the preparation of carbo- and heterocycles in a highly regio- and stereospecific manner. ${ }^{1-4}$ One of the challanges in the nineties is to control the stereochemistry of organic reactions. Although tremendous progress has been made in the field of metalcatalyzed enantioselective $\mathrm{C}-\mathrm{C}$ bond formation reactions, ${ }^{5}$ the control of the regio- and enantioselectivity of the different types of DA reactions is still far from satisfactory. It is therefore not surprising that considerable attention has been focused on the development of metal-catalyzed asymmetric variants of these DA reactions. ${ }^{2}$

In the field of hetero DA reactions of dienes with carbonyl compounds impressive results have been obtained by $\mathrm{Nakai}^{6-9}$ and Mikami ${ }^{6-12}$ using chiral binol-titanium complexes as the catalysts. The chiral binol-titanium complex catalyzed reaction of different dienes with alkyl glyoxylates lead to both the hetero DA product and ene product, with the latter as the major product. We have recently shown that the high ene to DA selectivity obtained by the chiral binol-titanium complex catalysts can be circumvented by the use of copper(II)-bisoxazoline complexes as the catalysts. ${ }^{13}$ 
Moreover attempts to use vanadium- and lanthanide complexes, and Kogas catalyst, for the hetero DA reaction have also been performed. ${ }^{14,15}$ It should also be noted that a chiral boron Lewis acid has recently been shown to be an excellent catalyst for the hetero DA reaction between Danishefsky's diene and methyl glyoxylate. ${ }^{16}$

In this paper we present an improved procedure for the metal-catalyzed asymmetric reaction of dienes with alkyl glyoxylates using especially the copper(II) bisoxazoline (S)-1a as the catalyst.

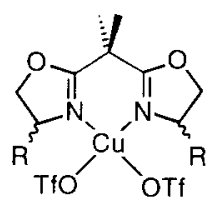

$$
\begin{aligned}
& \text { (S)-1a: } \mathrm{R}=t-\mathrm{Bu} \\
& (R)-1 \mathrm{~b}: \mathrm{R}=\mathrm{Ph}
\end{aligned}
$$

Recently Evans et al. showed that the catalytic properties of the weak Lewis acid (S)-1a could be improved by the use of a weakly coordinating anion such as hexafluoro antimone instead of the triflate anion. ${ }^{17}$ The accelerating effect is probably caused by a higher degree of ligand dissociation from the metal. We anticipated the same effect could take place by the use of a more polar solvent, which could stabilise the dissociating ions. ${ }^{18}$ This paper shows that using especially nitroalkanes as the solvent leads to a significant improvement of the catalytic properties of (S)-1a in the hetero DA reaction of dienes with alkyl glyoxylates.

\section{Results and discussion}

The reaction of a simple diene, such as 1,3-cyclohexadiene $\mathbf{2 a}$ and different alkyl glyoxylates $3 \mathbf{a}, \mathbf{b}$ leading to the hetero DA products $4 \mathbf{a}, \mathbf{b}$ has been studied in the presence of $(S)-\mathbf{1} \mathbf{a}$ and $(R)-\mathbf{1} \mathbf{b}$ as the catalysts and in different solvents [reaction (1)]. For experimental details see Experimental section.

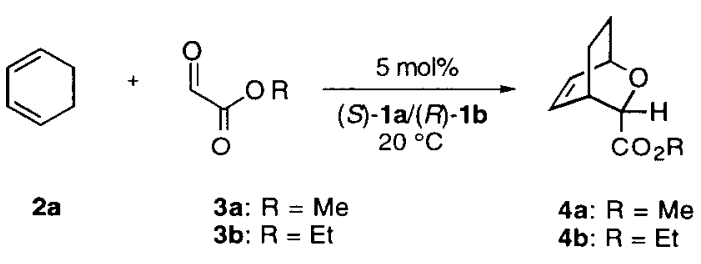


The hetero DA reaction of $2 \mathbf{a}$ with $3 \mathbf{a}, \mathbf{b}$ in the presence of $(S)-1 \mathbf{a}$ as the catalyst is very slow in $\mathrm{CH}_{2} \mathrm{Cl}_{2}$. The result is in sharp contrast to that of $2 \mathbf{a}$ with $3 \mathbf{b}$ in the presence $(R)-1 \mathrm{~b}$ as the catalyst in the same solvent which gave exclusively the endo-diastereomer of $\mathbf{4 b}$ in $72 \%$ yield with an ee of $60 \% .{ }^{13}$ A series of reactions of $2 a$ with $3 a, b$ has been performed in more polar solvents, such as nitroalkanes, acetonitrile, THF or DMF. It is found that especially the reactions in the nitroalkane solvents lead to a smooth formation of the hetero DA products $4 \mathbf{a}, \mathbf{b}$ and the results are presented in Table 1. In contrast, the use of acetonitrile, THF or DMF as solvents give only traces of the hetero DA product with low enantioselectivity.

Table 1. Hetero Diels-Alder reaction between 1,3-cyclohexadiene 2a and different alkyl glyoxylates $\mathbf{3} \mathbf{a}, \mathbf{b}$ catalyzed by $(S)-\mathbf{1} \mathbf{a}$ and $(R)-\mathbf{1} \mathbf{b}$ in $\mathrm{CH}_{3} \mathrm{NO}_{2}$ and $\left(\mathrm{CH}_{3}\right)_{2} \mathrm{CHNO}_{2} \cdot{ }^{\mathrm{a}}$

\begin{tabular}{|c||cccc|}
\hline Entry & Catalyst & Glyoxylate & Solvent & $\begin{array}{c}\text { Diels-Alder } \\
\text { Product } \\
\text { Yield } / \% \text { b }(e e)^{c}\end{array}$ \\
\hline \hline 1 & $(S)-\mathbf{1 a}$ & $\mathbf{3 b}$ & $\left(\mathrm{CH}_{3}\right)_{2} \mathrm{CHNO}_{2}$ & $\mathbf{4 b} 71(96)^{\mathrm{d}}$ \\
2 & $(S)-\mathbf{1 a}$ & $\mathbf{3 b}$ & $\mathrm{CH}_{3} \mathrm{NO}_{2}$ & $\mathbf{4 b} 66(97)^{\mathbf{d}}$ \\
3 & $(S)-\mathbf{1 a}$ & $\mathbf{3 a}$ & $\mathrm{CH}_{3} \mathrm{NO}_{2}$ & $\mathbf{4 a} 63(92)^{\mathrm{d}}$ \\
4 & $(R)-\mathbf{1} \mathbf{b}$ & $\mathbf{3 a}$ & $\mathrm{CH}_{3} \mathrm{NO}_{2}$ & $\mathbf{4 a} 49(29)^{\mathbf{e}}$ \\
5 & $(R)-\mathbf{1 b}$ & $\mathbf{3 a}$ & $\mathrm{CH}_{2} \mathrm{Cl}_{2}$ & $\mathbf{4 a} 63(47)^{\mathrm{d}}$ \\
\hline
\end{tabular}

a: All the reactions were carried out on a $1 \mathrm{mmol}$ scale, with $5 \mathrm{~mol} \%$ of the catalyst present.

b: Isolated yield.

c: Ee determined by GC on a Chrompack Chirasil-DEX CB column.

$\mathrm{d}$ : The absolute stereochmistry has been assigned as: $(1 R, 3 S, 4 S)$.

e: Inverse stereochemistry: $(1 S, 3 R, 4 R)$.

It appears from the results in Table 1 that a smooth hetero DA reaction of $2 \mathrm{a}$ with $3 \mathbf{a}, \mathbf{b}$ takes place in both $\mathrm{CH}_{3} \mathrm{NO}_{2}$ and $\left(\mathrm{CH}_{3}\right)_{2} \mathrm{CHNO}_{2}$ as the solvents when ( $\mathrm{S}$ )-1a is applied as the catalyst. In both solvents the endo-diastereomers of the hetero DA products $\mathbf{4 a}, \mathbf{b}$ are isolated in high yield and with ee's $>92 \%$. It is notable that the com- 
bination of ethyl glyoxylate as the dienophile and $\mathrm{CH}_{3} \mathrm{NO}_{2}$ as the solvent leads to an ee of $97 \%$ of the hetero DA product $4 \mathbf{b}$ (Table 1, entry 2). It is also interesting to note that hetero DA reaction of $\mathbf{2 a}$ with $\mathbf{3} \mathbf{a}, \mathbf{b}$ using $(R)-\mathbf{1} \mathbf{b}$ as the catalyst in nitroalkene solvents causes a reduction of the yield of the hetero DA product, as well as inversing the sence of enantioselectivity (entries 4,5 ). We are not at the present stage able to fully account for the change in enantioselectivity, it could be due to a change in structure of the catalytic intermediate of the reaction. ${ }^{13}$

To investigate the catalytic and synthetic potential of the hetero DA reaction in $\mathrm{CH}_{3} \mathrm{NO}_{2}$ as the solvent, the reaction of $2 \mathrm{a}$ with $3 \mathbf{b}$ was performed with only $0.5 \mathrm{~mol} \%$ $\mathrm{Cu}(\mathrm{OTf})_{2}$ and $0.75 \mathrm{~mol} \%$ of the bisoxazoline ligand as the catalytic system ((S)-1a). The hetero DA product $4 \mathrm{~b}$ can be converted into the valuable bicyclic lactone 5 , using the previously reported method (Scheme 1 ). ${ }^{13}$ The highly valuable synthon for sesquiterpene lactones 5 is isolated in $60 \%$ yield and with an ee $>99.8 \%$ after recrystallization. The sequence outlined in Scheme 1 is superior to the earlier one reported, although none of them was optimised. As can be seen from Scheme 1 both the diastereoselectivity and the ee of the DA product $4 \mathbf{b}$ is still very high, although less than $1 \mathrm{~mol} \%$ of the catalyst is applied. The reaction is slightly slower when applying the minor amount of catalyst, which can be seen by comparison with Table 1, entry 2 as $59 \%$ yield of $4 \mathbf{b}$ is obtained with only $0.5 \mathrm{~mol} \%$ of $\mathrm{Cu}(\mathrm{OTf})_{2}$.

Scheme 1:<smiles>CCOC(=O)C=O</smiles>

2a

3b

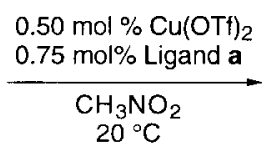

$59 \%$

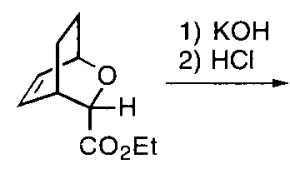

$\mathbf{4 b}$

$95 \%$ ee $100 \%$ endo

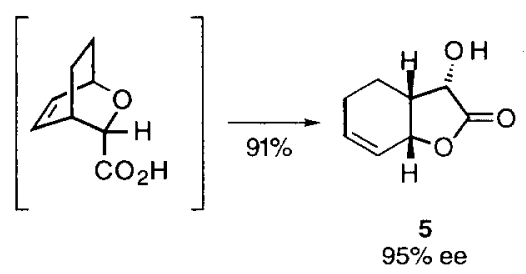

$\underset{60 \%}{\stackrel{\text { Cryst. }}{\longrightarrow}}$<smiles>O=C1O[C@H]2C=CCC[C@H]2[C@H]1O</smiles>

5

$>99.8 \%$ ee

The influence of the solvent on the hetero DA:ene ratio and the ee of the products has also been investigated. The diene chosen is 2,3 -dimethyl-1,3-butadiene $2 \mathrm{~b}$ 
which has the ability to undergo both a hetero DA reaction and an ene reaction. The reaction of $\mathbf{2 b}$ with the two alkyl glyoxylates $\mathbf{3} \mathbf{a}, \mathbf{b}$ leading to the hetero DA- and ene products, $6 \mathbf{a}, \mathbf{b}$ and $\mathbf{7 a}, \mathbf{b}$, respectively, is outlined in reaction (2). The reaction has also been studied in the less polar solvent $\mathrm{CH}_{2} \mathrm{Cl}_{2}$, as we have found that $2 b$ is able to undergo reaction with $\mathbf{3 b}$ in this solvent, and the results in $\mathrm{CH}_{2} \mathrm{Cl}_{2}$ will be compared with the reaction in $\mathrm{CH}_{3} \mathrm{NO}_{2}$.

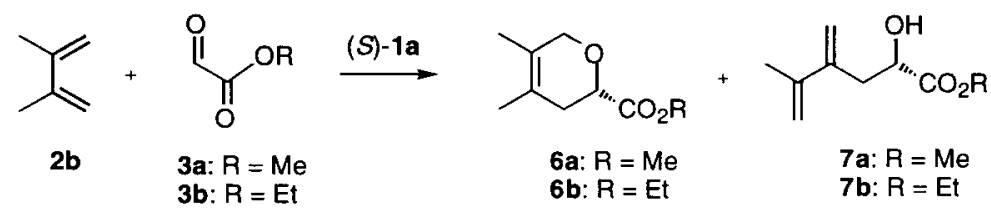

The results for the reaction of 2,3-dimethyl-1,3-butadiene $\mathbf{2 b}$ with the two alkyl glyoxylates $3 \mathbf{a}, \mathbf{b}$ in the presence of (S)-1a as the catalyst in $\mathrm{CH}_{2} \mathrm{Cl}_{2}$ and $\mathrm{CH}_{3} \mathrm{NO}_{2}$ are presented in Table 2.

Table 2. Reaction of 2,3-dimethyl-1,3-butadiene $2 \mathrm{~b}$ with alkyl glyoxylates $3 \mathbf{a}, \mathbf{b}$ in the presence of (S)-1a as the catalyst in $\mathrm{CH}_{2} \mathrm{Cl}_{2}$ or $\mathrm{CH}_{3} \mathrm{NO}_{2}$.

\begin{tabular}{|c|c|c|c|c|c|}
\hline Entry & Solvent & Glyoxylate & $\begin{array}{c}\text { Diels-Alder } \\
\text { Product } \\
\text { Yield } / \%^{\mathrm{a}}(\mathrm{ee})^{\mathrm{b}} \\
\text { (config.) }\end{array}$ & $\begin{array}{c}\text { Ene } \\
\text { Product } \\
\text { Yield /\%a } \\
(\mathrm{ee})^{\mathrm{b}, \mathrm{c}}\end{array}$ & $\begin{array}{c}\text { DA:Ene } \\
\text { Product Ratio }\end{array}$ \\
\hline 1 & $\mathrm{CH}_{2} \mathrm{Cl}_{2}$ & $3 b$ & $\mathbf{6 b} 20(85)(S)$ & $7 \mathrm{~b} 36(83)$ & $1: 1.8$ \\
\hline 2 & $\mathrm{CH}_{3} \mathrm{NO}_{2}$ & $3 \mathbf{b}$ & 6b $38(90)(S)$ & $7 b 30(78)$ & $1: 0.8$ \\
\hline 3 & $\mathrm{CH}_{3} \mathrm{NO}_{2}$ & $3 a$ & $\mathbf{6 a} 44(89)(S)$ & $7 a 35(73)$ & $1: 0.8$ \\
\hline
\end{tabular}

a: Isolated yield.

b: Ee determined by GC on a Chrompack Chirasil-DEX CB column.

c: Absolute stereochemistry not assigned.

It appears from Table 2 that a change of solvent has a signficant impact on both the DA to ene ratio, as well as the enantioselectivity. The DA:ene ratio is changed from 1:1.8 to 1:0.8 when changing the solvent from $\mathrm{CH}_{2} \mathrm{Cl}_{2}$ to $\mathrm{CH}_{3} \mathrm{NO}_{2}$ (Table 2, entries 1,2), 
showing that the relative amount of the hetero DA product has increased when $\mathrm{CH}_{3} \mathrm{NO}_{2}$ is used as the solvent compared with $\mathrm{CH}_{2} \mathrm{Cl}_{2}$ as the solvent. Moreover the total yield of the reaction is also larger when applying $\mathrm{CH}_{3} \mathrm{NO}_{2}$ as the solvent (entries 1,2 ). At the same time the ee for the DA product has improved by $5 \%$ to $90 \%$, while the ee of the ene product is reduced to $78 \%$. As may be observed, the methyl glyoxylate $\mathbf{3 b}$ gives slightly lower ee as compared with the reaction with ethyl glyoxylate $\mathbf{3 b}$ (entries 2,3). This is in contrast to the observations made in $\mathrm{CH}_{2} \mathrm{Cl}_{2}$ as the solvent. ${ }^{13} \mathrm{It}$ should also be pointed out that the hetero DA:ene ratio and the ee of the hetero DA product for the reaction of $\mathbf{2} \mathbf{b}$ with $\mathbf{3 b}$ in the presence of $(S)-\mathbf{1 a}$ as the catalyst and in $\mathrm{CH}_{3} \mathrm{NO}_{2}$ as the solvent is a significant improvement compared with the same reaction performed with $(R)-\mathbf{1 b}$ as the catalyst in $\mathrm{CH}_{2} \mathrm{Cl}_{2}$.

\section{Conclusion}

The use of nitroalkanes as solvent for the reaction of dienes with alkyl glyoxylates especially in the presence of 2,2-Isopropylidenebis[(4S)-4-tert-butyl-2-oxazoline]$\mathrm{Cu}(\mathrm{OTf})_{2}$ as the catalytic system, leads to a significant improvement of both the hetero DA product:ene produt ratio as the hetero DA adduct is formed as the major compound. Furthermore, the hetero DA adduct is formed with a very high ee in the nitroalkane solvents. In the reaction of 1,3-cyclohexadiene with ethyl glyoxylate an ee of $97 \%$ is obtained. This reaction is used for the synthesis of a synthon for highly valuable sesquiterpene lactones with an ee $>99.8 \%$.

\section{Experimental}

General. 2,3-Dimethyl-1,3-butadiene, 1,3-cyclohexadiene, 2,2'-Isopropylidenebis[(4S)4-tert-butyl-2-oxazoline] (Ligand a), (R)-2,2'-Isopropylidenebis(4-phenyl-2-oxazoline) (Ligand $\mathbf{b}$ ), and $\mathrm{Cu}(\mathrm{OTf})_{2}$ were purchased from Aldrich Chemical $\mathrm{Co}$. and used without further purification. $\mathrm{Cu}(\mathrm{OTf})_{2}$ was stored under $\mathrm{N}_{2}$. 1,3-Butadiene were purchased from Fluka and used as received. Solvents were dried according to standard procedures. The alkyl glyoxylates 3a-c were prepared as described in the literature, ${ }^{19,20}$ stored over $\mathrm{P}_{2} \mathrm{O}_{5}$ at $-18^{\circ} \mathrm{C}$ and distilled prior to use. Purification of reaction products was carried out by flash chromatography (fc) using Merck silica gel 60 (230-400 mesh). Tlc was performed on Merck analytical silica gel $60 \mathrm{~F}_{254}$ plates and visualised with a basic $\mathrm{KMnO}_{4}$ solution. ${ }^{1} \mathrm{H}$ and ${ }^{13} \mathrm{C}$ NMR spectra were recorded at $300 \mathrm{MHz}$ and 75 $\mathrm{MHz}$ using $\mathrm{CDCl}_{3}$ as the solvent and are reported in ppm downfield from TMS. Enantiomeric excess (ee) were determined by GC using a Chrompack Chirasil-DEX $\mathrm{CB}$ column. 
General Procedure for the Catalytic DA Reaction and Ene Reaction: Preparation of (S)-(-)-Ethyl 4,5-dimethyl-3,6-dihydro-2H-pyran-2-carboxylate 6b and (+)-Ethyl 2hydroxy-5-methyl-4-methylene-5-hexenoate $7 \mathrm{~b}$.

$\mathrm{Cu}(\mathrm{OTf})_{2}(36 \mathrm{mg}, 0.1 \mathrm{mmol})$ and ligand a $(31 \mathrm{mg}, 0.105 \mathrm{mmol})$ were combined in a glove box under $\mathrm{N}_{2} .1 \mathrm{~mL}$ of $\mathrm{CH}_{3} \mathrm{NO}_{2}$ was added under an $\mathrm{N}_{2}$ stream and mechanical stirring was performed for $1-2 \mathrm{~h} .1 .0 \mathrm{mmol}$ ethyl glyoxylate $(0.102 \mathrm{~g})$ dissolved in $1 \mathrm{~mL}$ of $\mathrm{CH}_{3} \mathrm{NO}_{2}$ and $1.5 \mathrm{mmol}$ 2,3-dimethyl-1,3-butadiene $(0.17 \mathrm{~mL})$ were added by canula and stirred for $12 \mathrm{~h}$. After evaporation the products were purified by Flash chromatography (18 cm * $1.5 \mathrm{~cm}$ silica gel, 2:8 ethyl acetate/heptane). Yield: DA product (70 $\mathrm{mg}, 38 \%$ ) and the ene product $(55 \mathrm{mg}, 30 \%$ ) as colourless oils.

6b: ${ }^{1} \mathrm{H}$ NMR: $4.28-4.03\left(\mathrm{~m}, 5 \mathrm{H}, 2 \mathrm{OCH}_{2}, \mathrm{OCH}\right), 2.36-2.15\left(\mathrm{br} \mathrm{m}, 2 \mathrm{H}, \mathrm{CH}_{2}\right), 1.67(\mathrm{~s}, 3 \mathrm{H}$, $\left.\mathrm{CH}_{3}\right), 1.54\left(\mathrm{~s}, 3 \mathrm{H}, \mathrm{CH}_{3}\right), 1.33-1.28\left(\mathrm{t}, 3 \mathrm{H}, J=7.1 \mathrm{~Hz}, \mathrm{CH}_{3}\right) .{ }^{13} \mathrm{C} \mathrm{NMR:} 171.6,124.2,122.5$, $72.9,69.2,61.0,33.0,18.2,14.2,13.8$.

$90 \%$ ee.

7b: 1H NMR: 5.25 (s, 1H, C=CH), $5.14(\mathrm{~s}, 1 \mathrm{H}, \mathrm{C}=\mathrm{CH}), 5.11(\mathrm{~s}, 1 \mathrm{H}, \mathrm{C}=\mathrm{CH}), 5.05(\mathrm{~s}, 1 \mathrm{H}$, $\mathrm{C}=\mathrm{CH}), 4.37-4.30(\mathrm{~m}, 1 \mathrm{H}, \mathrm{OCH}), 4.27-4.19\left(\mathrm{~m}, 2 \mathrm{H}, \mathrm{OCH}_{2}\right), 2.90-2.84(\mathrm{dd}, 1 \mathrm{H}, J=3.3$, $14.3 \mathrm{~Hz}, \mathrm{CH}), 2.67-2.65(\mathrm{~d}, 1 \mathrm{H}, J=6.6 \mathrm{~Hz}, \mathrm{OH}), 2.59-2.51(\mathrm{dd}, 1 \mathrm{H}, J=8.2,14.3 \mathrm{~Hz}, \mathrm{CH})$, $1.94\left(\mathrm{~s}, 3 \mathrm{H}, \mathrm{CH}_{3}\right), 1.33-1.28\left(\mathrm{t}, 3 \mathrm{H}, J=7.1 \mathrm{~Hz}, \mathrm{CH}_{3}\right) .{ }^{13} \mathrm{C} \mathrm{NMR}: 174.6,142.7,142.1,115.7$, $113.4,69.5,61.6,39.2,21.2,14.2$.

$78 \%$ ee.

Reaction of ethyl glyoxylate and 1,3-cyclohexadiene (Synthesis of the bicyclic lactone 5). $\mathrm{Cu}(\mathrm{OTf})_{2}(36 \mathrm{mg}, 0.1 \mathrm{mmol})$ and ligand a $(45 \mathrm{mg}, 0.15 \mathrm{mmol})$ were combined in a glove box under $\mathrm{N}_{2} 2 \mathrm{~mL}$ of $\mathrm{CH}_{3} \mathrm{NO}_{2}$ was added under an $\mathrm{N}_{2}$ stream and mechanical stirring was performed for 1-2 h. $20.0 \mathrm{mmol}$ ethyl glyoxylate $(2.04 \mathrm{~g})$ dissolved in $5 \mathrm{~mL}$ of $\mathrm{CH}_{3} \mathrm{NO}_{2}$ and $30.0 \mathrm{mmol}$ cyclohexadiene $(2.86 \mathrm{~mL})$ were added by canula and stirred for $20 \mathrm{~h} . \mathrm{CH}_{3} \mathrm{NO}_{2}$ was removed in vacuo and the residue was filtered through silica gel $(8.5 \mathrm{~cm} * 2.5 \mathrm{~cm})$ using $300 \mathrm{~mL} \mathrm{3:2}$ p-ether/ether. Yield: $2.136 \mathrm{~g}$ $(59 \%)$ after concentration in vacuo. To the cycloadduct was added a solution of $4 \mathrm{~mL}$ $\mathrm{H}_{2} \mathrm{O}, 6.6 \mathrm{~mL}$ EtOH and $1.78 \mathrm{~g}(36.4 \mathrm{mmol}) \mathrm{KOH}$. The solution was stirred under a gentle reflux for $90 \mathrm{~min}$. and partly evaporated (4 mL total volume) in vacuo. $5 \mathrm{~mL}$ $\mathrm{H}_{2} \mathrm{O}$ was added and after $5 \mathrm{~min}$ stirring $6 \mathrm{M} \mathrm{HCl}$ was added until the solution became acidic ( $\mathrm{pH} 2-3)$. After $14 \mathrm{~h}$ with stirring at 50-60 ${ }^{\circ} \mathrm{C}$ the product was extracted from the aqueous phase with ether $\left(5 \times 30 \mathrm{~mL} \mathrm{Et}_{2} \mathrm{O}\right)$. The residual aquous phase was evaporated until dryness, and $80 \mathrm{ml}$ ether was added. After $5 \mathrm{~min}$. reflux all the etheral phases were combined and dried with $\mathrm{MgSO}_{4}$ and evaporated until dryness. Yield: $91 \%(95 \%$ ee). The raw product contains only small amounts of impurities according 
to NMR spectroscopy. Recrystallisation from iso- $\mathrm{Pr}_{2} \mathrm{O}$ gives the almost enantiopure (> $99.8 \%$ ) bicyclic lactone in $60 \%$ yield. The procedure was not optimised.

Ethyl 2-oxa-bicyclo[2.2.2]oct-5-ene-3-carboxylate $4 \mathrm{~b}:{ }^{1} \mathrm{H}$ NMR: 6.54-6.50 (m, $1 \mathrm{H}$, $\mathrm{C}=\mathrm{CH}), 6.28-6.24(\mathrm{~m}, 1 \mathrm{H}, \mathrm{C}=\mathrm{CH}), 4.59-4.56(\mathrm{~m}, 1 \mathrm{H}, \mathrm{OCH}), 4.29$ (br s, $1 \mathrm{H}, \mathrm{OCH}), 4.18$ $4.13\left(\mathrm{q}, 2 \mathrm{H}, J=7.1 \mathrm{~Hz}, \mathrm{OCH}_{2}\right), 3.10-3.08(\mathrm{~m}, 1 \mathrm{H}, \mathrm{CH}), 2.10-2.01(\mathrm{~m}, 1 \mathrm{H}, \mathrm{CH}), 1.78-1.70$ $(\mathrm{m}, 1 \mathrm{H}, \mathrm{CH}), 1.43-1.26(\mathrm{~m}, 2 \mathrm{H}, 2 \mathrm{CH}), 1.21-1.26\left(\mathrm{t}, 3 \mathrm{H}, J=7.1 \mathrm{~Hz}, \mathrm{CH}_{3}\right) .{ }^{13} \mathrm{C} \mathrm{NMR}$ : $172.2,134.6,130.5,74.1,66.4,60.7,33.2,25.6,20.8,14.2$.

(1R,3S,4S)-9-Hydroxy-7-oxabicyclo [4.3.0] non-4-en-8-one 5: ${ }^{1} \mathrm{H}$ NMR: 6.28-6.22 (m, $1 \mathrm{H}, \mathrm{C}=\mathrm{CH}), 5.97-5.92(\mathrm{~m}, 1 \mathrm{H}, \mathrm{C}=\mathrm{CH}), 4.73-4.68(\mathrm{~m}, 2 \mathrm{H}, 2 \mathrm{OCH}), 2.93(\mathrm{br} \mathrm{s}, 1 \mathrm{H}, \mathrm{OH})$, 2.77-2.67 (m, 1H, CH), 2.28-2.17 (m, 1H, CH), 2.08-1.98 (m, 1H, CH), 1.96-1.91 (m, 1H, $\mathrm{CH}), 1.29-1.13(\mathrm{~m}, 1 \mathrm{H}, \mathrm{CH}) .{ }^{13} \mathrm{C}$ NMR: $177.3,136.6,121.6,71.8,71.5,39.1,23.1,17.3$. $[\alpha]_{\mathrm{D}}^{20}-142^{\circ}\left(\mathrm{c} 1.2 \mathrm{CHCl}_{3}\right)>99.8 \%$ ee.

\section{References}

1. Narasaka, K. Synthesis 1991, 1.

2. Kagan, H. B.; Riant, O. Chem. Rev. 1992, 92, 1007.

3. Pindur, U.; Lutz, G.; Otto, C. Chem. Rev. 1993, 93, 741.

4. Waldmann, H. Synthesis 1994, 535.

5. Trost, B. M. Angew. Chem. Int. Ed. Engl. 1995, 34, 259.

6. Mikami, K.; Terada, M.; Narisawa, S.; Nakai, T. Synlett 1992, 255.

7. Mikami, K.; Terada, M.; Nakai, T. J. Am. Chem. Soc. 1989, 111, 1940.

8. Mikami, K.; Terada, M.; Nakai, T. J. Am. Chem. Soc 1990, 112, 3949.

9. Terada, M.; Mikami, K.; Nakai, T. Tetrahedron Lett. 1991, 32, 935.

10. Terada, M.; Matsukawa, S.; Mikami, K. J. Chem. Soc., Chem. Commun. 1993, 327.

11. Mikami, K.; Motoyama, Y.; Terada, M. J. Am. Chem. Soc. 1994, 116, 2812.

12. Terada, M.; Mikami, K. J. Chem. Soc., Chem. Commun. 1994, 833.

13. Johannsen, M.; Jørgensen, K. A. J. Org. Chem. 1995, 60, in press.

14. Quimpére, M.; Jankowski, K. J. Chem. Soc., Chem. Commun. 1987, 676.

15. Togni, A. Organometallics 1990, 9, 3106.

16. Motoyama, Y.; Mikami, K. J. Chem. Soc., Chem. Commun. 1994, 1563.

17. Evans, D. A.; Murry, J. A.; Matt, P.; Norcross, R. D.; Miller, S. J. Angew. Chem. Int. Ed. Engl. 1995, 34, 798.

18. Jaquith, J. B.; Guan, J.; Wang, S.; Collins, S. Organometallics 1995, 14, 1079.

19. Kelly, T. R.; Schmidt, T. E.; Haggerty, J. G. Synthesis 1972, 544.

20. Hook, J. M. Synthetic Communications 1984, 14, 83. 